\title{
Fungi in the indoor air of critical hospital areas: a review
}

\author{
Jenyffie A. Belizario • Leonardo G. Lopes $(\mathbb{D} \cdot$ Regina H. Pires $\mathbb{D}$
}

Received: 17 August 2020/Accepted: 17 April 2021/Published online: 14 May 2021

(C) The Author(s), under exclusive licence to Springer Nature B.V. 2021

\begin{abstract}
Invasive fungal infection is an important cause of mortality and morbidity in neonates, especially in low-birthweight neonates. The contribution of fungi in the indoor air to the incidence of mucocutaneous colonization and to the risk of invasive fungal infection in this population is uncertain. This review aimed to identify and to summarize the best available evidence on the fungal contamination in the indoor air of critical hospital areas with an emphasis on pediatric/neonatal ICUs. Publications from 2005 to 2019 were searched in the databases Scientific Electronic Library Online (SciELO), US National Library of Medicine National Institutes of Health Search (PubMed), and Latin American Caribbean Health Sciences (LILACS). Descriptors in Health Sciences (DeCS) were used. Research papers published in Portuguese, English, and Spanish were included. Twenty-nine papers on all continents except Australia were selected. The results showed that the air mycobiota contained several fungal species, notably Aspergillus, Penicillium, Cladosporium, Fusarium, and yeast (Candida) species. The selected papers point out the risks that fungi pose to neonates, who have immature immune system, and describe simultaneous external factors (air humidity,
\end{abstract}

J. A. Belizario · L. G. Lopes · R. H. Pires ( $\square)$

Universidade de Franca, Av. Dr. Armando Salles de

Oliveira, 201, Parque Universitário, Franca,

São Paulo 14404-600, Brazil

e-mail: regina.pires@unifran.edu.br seasonality, air and people flow, use of particulate filters, and health professionals' hand hygiene) that contribute to indoor air contamination with fungi. Improving communication among health professionals is a great concern because this can prevent major health complications in neonates, especially in lowbirthweight neonates. The results reinforced the need to monitor environmental fungi more frequently and efficiently in hospitals, especially in neonatal ICUs.

Keywords Indoor air - Nosocomial fungi · Opportunistic infections $\cdot$ Neonatal ICU

\section{Introduction}

Neonatal Intensive Care and Pediatric Intensive Care Units (NICUs and PICUs, respectively) are considered critical areas in hospital environments. In NICUs, health professionals deliver care to neonates, often premature, and patients assisted in NICUs and PICUs usually undergo invasive procedures, which contribute to significant morbidity and mortality in the neonatal period (Smith et al., 2018). Although some studies have addressed the role that indoor air plays in hospital-acquired infection (HAI), few data are available, and the relationship between airborne pathogens and the risk of HAI in the Intensive Care Unit (ICU), especially in NICUs, remain largely unknown. 
In developed countries, general infection rates in neonatal units reach over $20 \%$ of neonates with low birth weight (Hornik et al., 2012). In Brazil, HAI has been estimated to affect over $30 \%$ of neonates (Dal-Bo et al., 2012; Brazil, 2013).

On the basis of the onset of infection, neonatal sepsis has been classified into early- and late-onset sepsis (Shah \& Padbury, 2014). Early onset sepsis begins in the first three days of life and results mainly from vertical microorganism transmission from mothers to babies during the intrapartum period. Late-onset sepsis occurs after one week of life and is caused by horizontal transmission of pathogens acquired in the postnatal period. It generally presents with subtle and nonspecific clinical signs and symptoms at the start of infection, which can be misunderstood or confused with other noninfectious clinical conditions (Shah \& Padbury, 2014).

High infection rates in NICUs/PICUs have been attributed to working conditions, to the physical structure of the NICU/PICU, to the nurse/bed ratio, to the immunological immaturity and to the conditions of the neonate (mainly low birth weight and malnutrition), to the resident microbiota in the care assistance, to drug abuse by mothers, and to the presence of multiresistant microbial strains, among others (Smith et al., 2018).

Prematurity, low birth weight, prolonged catheter use, invasive procedures, ventilator-associated pneumonia, and prolonged antibiotic therapy have been considered risk factors for neonatal infection with Pseudomonas aeruginosa, Candida albicans, Serratia marcescens, and Escherichia coli, which in turn lead to high mortality rates (Karlowicz et al., 2000; Goldstein et al., 2016). Infections with Candida yeasts, mainly invasive forms, are serious and affect particularly critically ill patients and immunocompromised patients (Friedman \& Schwartz, 2019).

Newborns and young infants have an immature immune system and depend on the innate immune response effectiveness and passive protection of maternally acquired antibodies via the transplacental route (Yoon, 2010; Shah \& Padbury, 2014). A stimulus to the innate immune response corresponds to the activation of toll-like receptors (TLRs), which are expressed on the surface of monocytes, macrophages, dendritic cells, lymphocytes, and epithelial cells or in the cytoplasm of different tissue cells. At birth, the amount of TRLs depends on quantitative and qualitative changes that are proportional to the gestational age (Wynn \& Levy, 2010). In addition, at birth, the immune system presents lower production of proinflammatory cytokines, and these cytokines have less multifunctionality (Nguyen et al., 2010; Shah \& Padbury, 2014). Taken together, all these differences in the immune system of neonates can increase their susceptibility to infection (Wynn \& Levy, 2010; Shah \& Padbury, 2014).

In recent decades, filamentous fungi have increasingly been recognized as agents that cause nosocomial infections (Abbasi \& Samaei, 2019; Friedman \& Schwartz, 2019). Nevertheless, they remain largely neglected in hospital care quality regulations, particularly in NICUs/PICUs. Possible reasons for this situation may be the lack of knowledge of the fungal load (especially in the air), divergent culture methods, heterogeneous mechanisms of fungal pathogenicity, and, primarily, the low number of notifications that connect the presence of anemophilous fungi to the occurrence of diseases in humans (Mobin \& Salmito, 2006). Moreover, unlike the obvious outbreaks, these fungi are treated discretely, and their origin is rarely explored.

In this context, in this review we have conducted a survey of studies that address fungi grown in environmental samples (mainly air) from critical areas of hospital environments, with an emphasis on NICUs/ PICUs and ICUs.

\section{Methods}

This review was conducted following the recommendations outlined in the Preferred Reporting Items for Systematic Review and Meta-Analyzes (PRISMA) instrument (Moher et al., 2010). The searches were guided by the question "What is the frequency of fungal contamination in the ambient air of intensive care units, especially in neonatal ICUs?" This question was elaborated using the strategy PICo (problem, interest or phenomenon and context), which defined the problem as "fungi in ambient air," the interest as "fungal infections frequency" and the context as "neonatal intensive care units" (Check \& Schutt, 2012). 


\subsection{Search strategy}

The search period was determined based on the lack of studies identified in the preliminary searches when preparing the study protocol. Thus, papers published in the last 15 years were selected. Globally data were collected by consulting the database US National Library of Medicine (PubMed), the Latin American Caribbean Health Sciences (LILACS) to access the South American data, and the Scientific Electronic Library Online (SciELO), to access the national data. The Descriptors in Health Sciences (DeCS) or in Medical Subject Heading (MeSH) as "Intensive Care Units, Neonatal," "Fungi," "Indoor Air," and "Newborn" were employed as well as its synonym in Spanish and Portuguese.

\subsection{Studies inclusion and exclusion criteria}

Studies were included when they answered the guiding question and followed the criteria: original research articles published in English, Portuguese, or Spanish. In addition, only studies available in full online were selected since the abstracts tend to reduce studies to their key characteristics neglecting aspects that could be important in the interpretative synthesis of the data. Conference proceedings, theses, and dissertations were excluded given their potential for bias (Evans, 2002; Popay et al., 2006; Roen et al., 2006).

Next, the title and the summary of the articles were read, and only those that addressed the presence of fungi obtained from the environment (especially the air) in critical areas, including mainly the neonatal/pediatric/adult intensive care units, were selected. The articles that addressed infections of bacterial origin only and/or which dealt with determination/isolation of the fungus in specific areas (endotracheal tube, venous catheter) were excluded. Data were extracted by J.A.B. and L.G.L. and checked for completeness and accuracy by R.H.P.

\section{Results}

A total of 167 papers were identified in database searches. After removal of duplicates (22), the titles and abstracts of the remaining 145 papers were screened, of which 100 papers were excluded. The full texts of 45 papers were reviewed against following the inclusion and exclusion criteria; 16 were excluded, and 29 studies were selected (Fig. 1). We catalogued the articles according to the authorship and year of publication, the title, the sampled hospital area, the type of collected sample, and the identification of prevalent agents, as shown in Table 1.

\subsection{Collection and cultivation techniques}

Some authors used the passive sedimentation technique to collect air samples (Melo et al., 2009; Lobato et al., 2009; Sales et al., 2011; Awosika et al., 2012; Okten \& Asa, 2012; Pantoja et al., 2012; Aboul-Nasr et al., 2014; Gonçalves et al., 2018; Calumby et al., 2019; Souza et al., 2019). Open Petri dishes were exposed to air for between 10 and $30 \mathrm{~min}$ at a height of 80 to $150 \mathrm{~cm}$ from the floor. However, most authors employed air vacuum devices such as Anderson single-step model (10-710), MAS 100 Iso MH Microbial Air Sampler (Merck Millipore, Germany), SAS SUPER 100 (Merck), and LWC (Kangjie Instrument Research Institute, Liaoyang, China) at a variable flow rate $(28.3-100 \mathrm{~L} / \mathrm{min})$ to obtain the suspended particle concentration (Martins-Diniz et al., 2005; Krajewska-Kułak et al., 2007; Chuaybamroong et al., 2008; Quadros et al., 2009; Ortiz et al., 2009; Qudiesat et al., 2009; Gniadek et al., 2010; Kim et al., 2010; Boff et al., 2013; Macedo et al., 2013; Park et al., 2013; Hoseinzadeh et al., 2013; ElSharkawy \& Noweir, 2014; Maldonado-Vega et al., 2014; Yu et al., 2015; Gniadek et al., 2017; Abbasi \& Samaei, 2019). In some studies, material from inanimate surfaces (keyboards, phones, stethoscope, beds, door handles, walls, and equipment) was also collected by means of swabs or imprints (Martins-Diniz et al., 2005; Krajewska-Kułak et al., 2007; Melo et al., 2009; Qudiesat et al., 2009; Sales et al., 2011; AboulNasr et al., 2014).

Sabouraud dextrose agar added with the antibiotic chloramphenicol was used to culture the fungi (Martins-Diniz et al., 2005; Mobin \& Salmito, 2006; Chuaybamroong et al., 2008; Melo et al., 2009; Quadros et al., 2009; Qudiesat et al., 2009; Awosika et al., 2012; Pantoja et al., 2012; Boff et al., 2013; Maldonado-Vega et al., 2014; Yu et al., 2012; Gonçalves et al., 2018; Calumby et al., 2019). Authors as Okten and Asan (2012), Ortiz et al. (2009), and Maldonado-Vega et al. (2014) employed Bengal pink agar for primary isolation, while Macedo et al. (2013) 

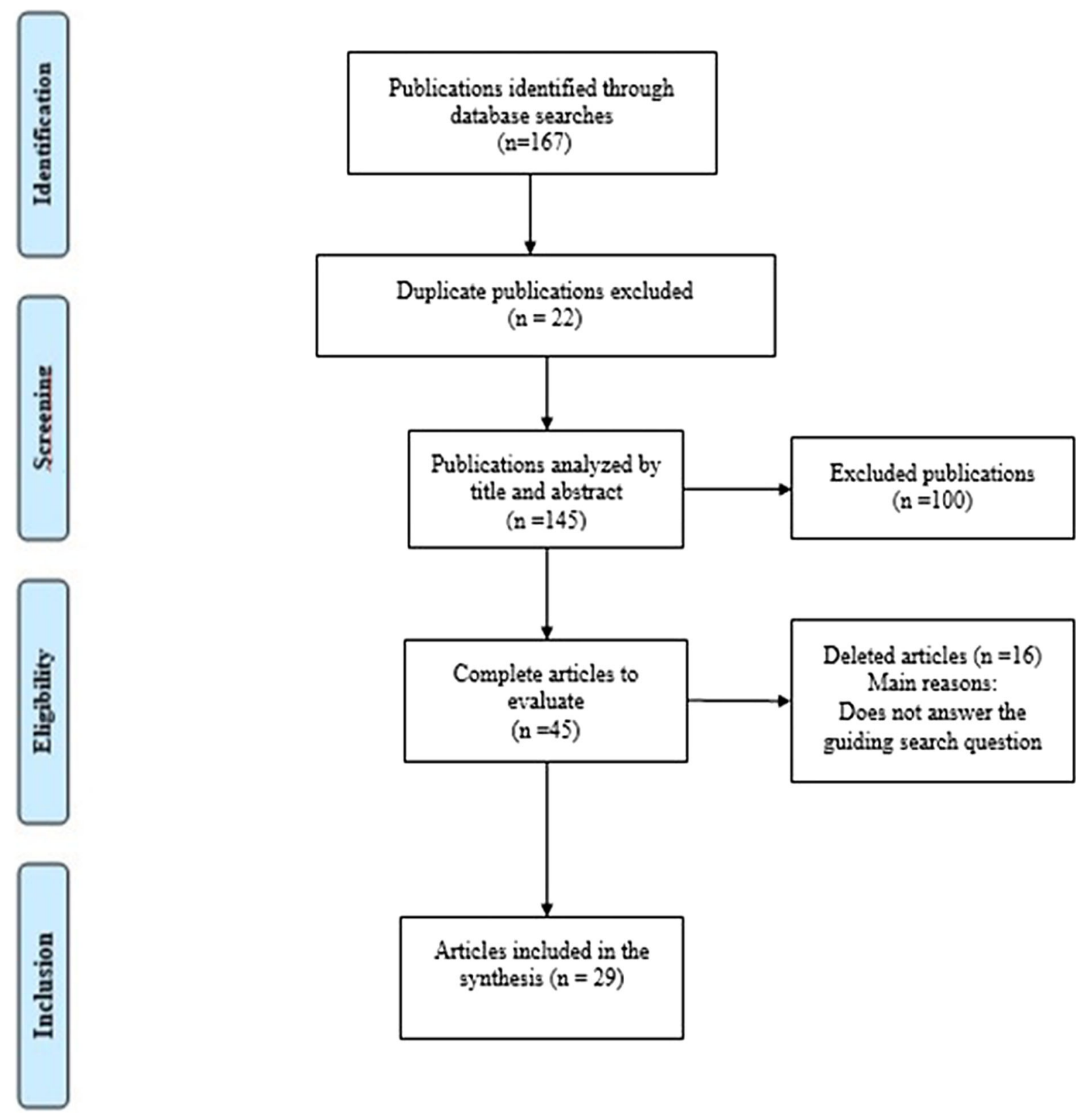

Fig. 1 Prisma flow diagram of studies searched in the databases Scientific Electronic Library Online (SciELO), US National Library of Medicine National Institutes of Health Search (PubMed), and Latin American Caribbean Health Sciences (LILACS)

used potato dextrose agar. To cultivate Penicillium and Aspergillus, Souza et al. (2019) employed three variations of the Czapek medium (with glucose, with glucose at $\mathrm{pH} 8.5$, and with cellulose), whereas Kim et al. (2010) used malt extract agar. Okten and Asan (2012) employed Czapek agar, malt extract agar, and nitrate agar with $25 \%$ glycerol.
To grow the fungi, the plates were incubated at room temperature or at $28{ }^{\circ} \mathrm{C}$ for $7-10$ days. Only Sales et al. (2011) used a temperature of $37^{\circ} \mathrm{C}$ to cultivate all the fungal isolates because they aimed to isolate fungi adapted to the human organism. 
Table 1 Distribution of primary studies selected according to author, title, collection site, collected material and prevalent fungi

\begin{tabular}{|c|c|c|c|c|}
\hline Author & Title & Site collected & Collected material & Prevalent fungi \\
\hline $\begin{array}{r}\text { Martins-Diniz } \\
\text { et al. (2005) }\end{array}$ & $\begin{array}{l}\text { Monitoring of airborne fungus and } \\
\text { yeast species in a hospital unit }\end{array}$ & $\begin{array}{l}\text { ICU } \\
\text { PICU } \\
\text { surgical center }\end{array}$ & $\begin{array}{l}\text { Indoor air, hands (nail beds } \\
\text { and interdigital spaces) } \\
\text { and oropharynx from } \\
\text { healthcare staff }\end{array}$ & $\begin{array}{l}\text { Cladosporium spp. } \\
\text { Fusarium spp. } \\
\text { Penicillium spp. } \\
\text { Aspergillus spp. } \\
\text { Alternaria } \text { spp. } \\
\text { Candida (C. albicans, } \\
\text { C. parapsilosis) }\end{array}$ \\
\hline $\begin{array}{l}\text { Mobin and } \\
\text { Salmito (2006) }\end{array}$ & $\begin{array}{l}\text { Fungus microbiota in air- } \\
\text { conditioners in intensive care } \\
\text { units in Teresina, Piauí }\end{array}$ & ICU & Air-conditioning filters & $\begin{array}{l}\text { Aspergillus niger } \\
\text { Aspergillus fumigatus } \\
\text { Trichoderma koningii } \\
\text { Aspergillus flavus }\end{array}$ \\
\hline $\begin{array}{l}\text { Krajewska- } \\
\text { Kułak et al. } \\
(2007)\end{array}$ & $\begin{array}{l}\text { Indoor air studies of fungi } \\
\text { contamination at the neonatal } \\
\text { department and intensive care unit } \\
\text { an palliative care in Kavala } \\
\text { Hospital in Greece }\end{array}$ & $\begin{array}{l}\text { Neonatal area, } \\
\text { including ICU }\end{array}$ & Indoor air, wall swabs & $\begin{array}{l}\text { Candida albicans } \\
\text { non-Candida albicans } \\
\text { Penicillium species } \\
\text { Acremonium spp. } \\
\text { Rhodotorula } \text { species } \\
\text { Aspergillus species }\end{array}$ \\
\hline $\begin{array}{l}\text { Chuaybamroong } \\
\text { et al. (2008) }\end{array}$ & $\begin{array}{l}\text { Comparison between hospital single } \\
\text { air unit and central air unit for } \\
\text { ventilation performances and } \\
\text { airborne microbes }\end{array}$ & $\begin{array}{l}\text { PICU } \\
\text { NICU } \\
\text { Birth room }\end{array}$ & Indoor air & Aspergillus spp. \\
\hline $\begin{array}{l}\text { Melo et al. } \\
\text { (2009) }\end{array}$ & $\begin{array}{l}\text { Environmental fungal flora in } \\
\text { pediatric and neonatal intensive } \\
\text { care units at a tertiary hospital }\end{array}$ & $\begin{array}{l}\text { PICU } \\
\text { NICU }\end{array}$ & $\begin{array}{l}\text { Swabs from bed, } \\
\text { incubators, windows, air- } \\
\text { conditioners, telephones, } \\
\text { stethoscopes, doors, and } \\
\text { knobs }\end{array}$ & $\begin{array}{l}\text { Aspergillus spp. } \\
\text { Cladosporium spp. } \\
\text { Penicillium spp. } \\
\text { Chrysosporium spp. } \\
\text { Candida } \text { spp. }\end{array}$ \\
\hline $\begin{array}{l}\text { Lobato et al. } \\
\text { (2009) }\end{array}$ & $\begin{array}{l}\text { Seasonality and prevalence of } \\
\text { airborne fungi in the hospital } \\
\text { environment on the south of Rio } \\
\text { Grande do Sul, Brazil }\end{array}$ & $\begin{array}{l}\text { NICU } \\
\text { ICU }\end{array}$ & Indoor air & $\begin{array}{l}\text { Cladosporium spp. } \\
\text { Aspergillus spp. } \\
\text { Alternaria spp. } \\
\text { Penicillium spp. } \\
\text { Rhodotorula spp. }\end{array}$ \\
\hline $\begin{array}{l}\text { Quadros et al. } \\
\text { (2009) }\end{array}$ & $\begin{array}{l}\text { Indoor air quality in hospitals: a } \\
\text { case study and a critical review of } \\
\text { current standards }\end{array}$ & $\begin{array}{l}\text { NICU } \\
\text { ICU } \\
\text { SC }\end{array}$ & Indoor air & $\begin{array}{l}\text { Aspergillus spp. } \\
\text { Penicillium spp. }\end{array}$ \\
\hline $\begin{array}{l}\text { Ortiz et al. } \\
(2009)\end{array}$ & $\begin{array}{l}\text { A study of air microbe levels in } \\
\text { different areas of a hospital }\end{array}$ & $\begin{array}{l}\text { Hospital rooms } \\
\text { (HR) } \\
\text { Maternity wards } \\
\text { (MW) }\end{array}$ & Indoor air & $\begin{array}{l}\text { Aspergillus spp. (A. } \\
\text { fumigatus, A. flavus), } \\
\text { Mucor spp. } \\
\text { Absidia } \text { spp. } \\
\text { Rhizopus spp. }\end{array}$ \\
\hline
\end{tabular}


Table 1 continued

\begin{tabular}{|c|c|c|c|c|}
\hline Author & Title & Site collected & Collected material & Prevalent fungi \\
\hline $\begin{array}{l}\text { Qudiesat et al. } \\
\text { (2009) }\end{array}$ & $\begin{array}{l}\text { Assessment of airborne pathogens } \\
\text { in healthcare settings }\end{array}$ & $\begin{array}{l}\text { ICU } \\
\text { SC } \\
\text { neonatal ward } \\
\text { main entrance of } \\
\text { the hospital } \\
\text { patient room }\end{array}$ & $\begin{array}{l}\text { Indoor air } \\
\text { surface swabs (operation } \\
\text { rooms, neonatal wards, } \\
\text { the air-conditioning } \\
\text { systems, ventilation grills) }\end{array}$ & $\begin{array}{l}\text { Aspergillus spp. } \\
\text { Penicillium spp. }\end{array}$ \\
\hline $\begin{array}{l}\text { Gniadek et al. } \\
(2010)\end{array}$ & $\begin{array}{l}\text { Cytotoxicity of Aspergillus strains } \\
\text { isolated from the neonatal } \\
\text { intensive care unit environment }\end{array}$ & NICU & Indoor air & $\begin{array}{l}\text { Penicillium spp. } \\
\text { Aspergillus (A. } \\
\text { fumigatus, A. } \\
\text { ochraceus, A. niger } \\
\text { and A. glaucus) } \\
\text { Cladosporium spp. }\end{array}$ \\
\hline Kim et al. (2010) & $\begin{array}{l}\text { Distribution characteristics of } \\
\text { airborne bacteria and fungi in the } \\
\text { general hospitals of Korea }\end{array}$ & $\begin{array}{l}\text { main lobby } \\
\text { SC } \\
\text { ICU } \\
\text { biomedical } \\
\text { laboratory }\end{array}$ & Indoor air & $\begin{array}{l}\text { Cladosporium spp. } \\
\text { Penicillium spp. } \\
\text { Aspergillus spp. } \\
\text { Alternaria spp. }\end{array}$ \\
\hline $\begin{array}{l}\text { Sales et al. } \\
\text { (2011) }\end{array}$ & $\begin{array}{l}\text { Airborne fungi in an intensive care } \\
\text { units and a surgical center of a } \\
\text { university hospital }\end{array}$ & $\begin{array}{l}\text { ICU } \\
\text { NICU } \\
\text { SC } \\
\text { external areas }\end{array}$ & Air-conditioning filters & $\begin{array}{l}\text { Aspergillus spp. } \\
\text { Fusarium spp. }\end{array}$ \\
\hline $\begin{array}{l}\text { Awosika et al. } \\
\text { (2012) }\end{array}$ & $\begin{array}{l}\text { Microbiological assessment of } \\
\text { indoor air of a teaching hospital in } \\
\text { Nigeria }\end{array}$ & $\begin{array}{l}\text { male medical ward } \\
\text { female medical } \\
\text { ward } \\
\text { children's ward } \\
\text { NICU } \\
\text { male surgical } \\
\text { specialty } \\
\text { male surgical } \\
\text { general } \\
\text { female surgical } \\
\text { ward } \\
\text { SC } \\
\text { emergency unit }\end{array}$ & Indoor air & $\begin{array}{l}\text { Penicillium spp. } \\
\text { Aspergillus flavus, } \\
\text { Candida albicans }\end{array}$ \\
\hline $\begin{array}{l}\text { Venceslau et al. } \\
\text { (2012) }\end{array}$ & $\begin{array}{l}\text { Frequency of airborne fungus in } \\
\text { critical areas at hospital unit of } \\
\text { Aracaju, Sergipe, Brazil }\end{array}$ & $\begin{array}{l}\text { Urgency and } \\
\text { emergency } \\
\text { SC } \\
\text { ICU } \\
\text { NICU } \\
\text { Burned Therapy } \\
\text { Unit }\end{array}$ & Indoor air & $\begin{array}{l}\text { Aspergillus spp. } \\
\text { Penicillium spp. } \\
\text { Candida spp. } \\
\text { Fusarium spp. } \\
\text { Curvularia } \mathrm{spp} .\end{array}$ \\
\hline $\begin{array}{l}\text { Okten and Asan } \\
\text { (2012) }\end{array}$ & $\begin{array}{l}\text { Airborne fungi and bacteria in } \\
\text { indoor and outdoor environment } \\
\text { of the Pediatric Unit of Edirne } \\
\text { Government Hospital }\end{array}$ & Pediatric Service & Indoor or outdoor air & $\begin{array}{l}\text { Cladosporium spp. } \\
\text { Alternaria spp. } \\
\text { Penicillium spp. }\end{array}$ \\
\hline
\end{tabular}


Table 1 continued

\begin{tabular}{|c|c|c|c|c|}
\hline Author & Title & Site collected & Collected material & Prevalent fungi \\
\hline $\begin{array}{l}\text { Pantoja et al. } \\
\text { (2012) }\end{array}$ & $\begin{array}{l}\text { Fungal biodiversity of air in } \\
\text { hospitals in the city of Fortaleza, } \\
\text { Ceará, Brazil }\end{array}$ & $\begin{array}{l}\text { Hospital A (PICU) } \\
\text { Hospital B (ICU) } \\
\text { Hospital C (open } \\
\text { areas and } \\
\text { hospital } \\
\text { facilities) }\end{array}$ & Indoor air & $\begin{array}{l}\text { Aspergillus spp. } \\
\text { Penicillium,spp. } \\
\text { Candida,spp. } \\
\text { Curvularia spp. } \\
\text { Trichoderma spp. }\end{array}$ \\
\hline Boff et al. (2013) & $\begin{array}{l}\text { The indoor air as a potential } \\
\text { determinant of the frequency of } \\
\text { invasive aspergillosis in the } \\
\text { intensive care }\end{array}$ & ICU & $\begin{array}{l}\text { Indoor air } \\
\text { Outdoor air }\end{array}$ & $\begin{array}{l}\text { Cladosporium spp. } \\
\text { Penicillium spp. } \\
\text { Aspergillus spp. }\end{array}$ \\
\hline $\begin{array}{l}\text { Macedo et al. } \\
\text { (2013) }\end{array}$ & $\begin{array}{l}\text { Air quality in a hospital } \\
\text { environment }\end{array}$ & $\begin{array}{l}\text { ICU } \\
\text { NICU } \\
\text { Corridor } \\
\text { Outdoor Area }\end{array}$ & Indoor air & $\begin{array}{l}\text { Aspergillus spp } \\
\text { Penicillium spp. } \\
\text { Fusarium spp. }\end{array}$ \\
\hline Park et al. (2013) & $\begin{array}{l}\text { Assessment of the levels of airborne } \\
\text { bacteria, Gram-negative bacteria, } \\
\text { and fungi in hospital lobbies }\end{array}$ & Hospital facilities & Indoor air & $\begin{array}{l}\text { fungi were found at } \\
5.5 \times 10^{2} \mathrm{CFU} / \mathrm{m}^{3}\end{array}$ \\
\hline $\begin{array}{l}\text { Hoseinzadeh } \\
\text { et al. (2013) }\end{array}$ & $\begin{array}{l}\text { Evaluation of bioaerosols in five } \\
\text { educational hospitals wards air in } \\
\text { Hamedan, during 2011-2012 }\end{array}$ & $\begin{array}{l}\text { Emergency } \\
\text { SC } \\
\text { ICU } \\
\text { Isolation room }\end{array}$ & Indoor air & $\begin{array}{l}\text { Penicillium spp. } \\
\text { Cladosporium spp. } \\
\text { Aspergillus fumigatus } \\
\text { Aspergillus niger }\end{array}$ \\
\hline $\begin{array}{l}\text { Aboul-Nasr et al. } \\
\text { (2014) }\end{array}$ & $\begin{array}{l}\text { Indoor surveillance of airborne } \\
\text { fungi contaminating Intensive } \\
\text { care units and operation rooms in } \\
\text { Assiut University Hospitals, } \\
\text { Egypt }\end{array}$ & $\begin{array}{l}\mathrm{ICU} \\
\mathrm{SC}\end{array}$ & $\begin{array}{l}\text { Indoor air, dust from air- } \\
\text { conditioning filters }\end{array}$ & $\begin{array}{l}\text { Cladosporium } \mathrm{sp} \\
\text { Aspergillus } \mathrm{sp} \\
\text { Penicillium } \mathrm{sp} \\
\text { Fusarium } \mathrm{sp}\end{array}$ \\
\hline $\begin{array}{l}\text { El-Sharkawy and } \\
\text { Noweir (2014) }\end{array}$ & $\begin{array}{l}\text { Indoor air quality levels in a } \\
\text { University Hospital in the Eastern } \\
\text { Province of Saudi Arabia }\end{array}$ & $\begin{array}{l}\text { main entrance of } \\
\text { the hospital } \\
\text { the burns unit } \\
\text { the laboratories } \\
\text { (both chemistry } \\
\text { and biology) } \\
\text { the emergency } \\
\text { department } \\
\text { ICU } \\
\text { the kitchen } \\
\text { the Outpatient } \\
\text { Department } \\
\text { SC } \\
\text { the pediatric unit }\end{array}$ & Indoor air & $\begin{array}{l}\text { Yeasts } \\
\text { Cladosporium sp } \\
\text { Penicillium } \mathrm{sp} \\
\text { Alternaria } \mathrm{sp}\end{array}$ \\
\hline $\begin{array}{l}\text { Maldonado- } \\
\text { Vega et al. } \\
\text { (2014) }\end{array}$ & $\begin{array}{l}\text { Bioaerosols and air quality } \\
\text { assessment in two hospitals } \\
\text { located in León, Guanajuato, } \\
\text { Mexico }\end{array}$ & $\begin{array}{l}\text { Waiting room } \\
\text { Chemotherapy } \\
\text { ICU } \\
\text { NICU/PICU } \\
\text { SC }\end{array}$ & Indoor air & $\begin{array}{l}\text { Fusarium ( } F . \\
\text { crookwellense, F. } \\
\text { equiseti, } F . \\
\text { semitectum, } F . \\
\text { solani, Fusarium } \\
\text { spp.) } \\
\text { Penicillium spp. }\end{array}$ \\
\hline
\end{tabular}


Table 1 continued

\begin{tabular}{|c|c|c|c|c|}
\hline Author & Title & Site collected & Collected material & Prevalent fungi \\
\hline Yu et al. (2015) & $\begin{array}{l}\text { Characteristics of airborne } \\
\text { microorganisms in a neurological } \\
\text { intensive care unit: results from } \\
\text { China }\end{array}$ & $\begin{array}{l}\text { Neurological } \\
\text { intensive care } \\
\text { unit }\end{array}$ & Indoor air & $\begin{array}{c}6.2 \% \text { of the samples } \\
\text { consisted of fungi }\end{array}$ \\
\hline $\begin{array}{l}\text { Gniadek et al. } \\
\text { (2017) }\end{array}$ & $\begin{array}{l}\text { Occurrence of fungi and } \\
\text { cytotoxicity of the species: } \\
\text { Aspergillus ochraceus, } \\
\text { Aspergillus niger and Aspergillus } \\
\text { flavus isolated from the air of } \\
\text { hospital wards }\end{array}$ & $\begin{array}{l}\text { ICU } \\
\text { NICU } \\
\text { General and } \\
\text { Systemic } \\
\text { Oncology Ward } \\
\text { Gynecological } \\
\text { Oncology } \\
\text { Hematology } \\
\text { (post bone } \\
\text { marrow } \\
\text { transplants) } \\
\text { Otolaryngology } \\
\text { (patients } \\
\text { diagnosed with } \\
\text { laryngeal } \\
\text { carcinoma) }\end{array}$ & Indoor air & $\begin{array}{l}\text { Aspergillus fumigatus } \\
\text { A. niger, } \\
\text { A. flavus } \\
\text { A. ochraceus }\end{array}$ \\
\hline $\begin{array}{l}\text { Gonçalves et al. } \\
\text { (2018) }\end{array}$ & $\begin{array}{l}\text { Airborne fungi in an intensive care } \\
\text { unit }\end{array}$ & ICU & Indoor air & $\begin{array}{l}\text { Penicillium spp. } \\
\text { Aspergillus spp. } \\
\text { Cladosporium spp. }\end{array}$ \\
\hline $\begin{array}{l}\text { Abbasi and } \\
\text { Samaei (2019) }\end{array}$ & $\begin{array}{l}\text { The effect of temperature on } \\
\text { airborne filamentous fungi in the } \\
\text { indoor and outdoor space of a } \\
\text { hospital }\end{array}$ & $\begin{array}{l}\text { NICU } \\
\text { Emergency } \\
\text { Obstetrics } \\
\text { Maternity } \\
\text { Biomedical } \\
\text { laboratory } \\
\text { Child surgery } \\
\text { Gynecology }\end{array}$ & Indoor air & $\begin{array}{l}\text { Fusarium spp., } \\
\text { Penicillium spp., } \\
\text { Paecilomyces spp, } \\
\text { Aspergillus niger }\end{array}$ \\
\hline $\begin{array}{l}\text { Calumby et al. } \\
\text { (2019) }\end{array}$ & $\begin{array}{l}\text { Isolation and identification of } \\
\text { anemophilic fungal microbiota in } \\
\text { an intensive care unit }\end{array}$ & ICU & Indoor air & $\begin{array}{l}\text { Cladosporium spp. } \\
\text { Aspergillus spp. } \\
\text { Penicillium spp. }\end{array}$ \\
\hline $\begin{array}{l}\text { Souza et al. } \\
\text { (2019) }\end{array}$ & $\begin{array}{l}\text { Airborne fungi in neonatal intensive } \\
\text { care unit of a public hospital in } \\
\text { Brazil }\end{array}$ & NICU & Indoor air & $\begin{array}{l}\text { Cladosporium spp } \\
\text { Pencillium } \mathrm{spp}, \\
\text { Aspergillus } \mathrm{spp} \\
\text { Candida parapsilosis } \\
\text { Candida } \\
\text { guilliermondii }\end{array}$ \\
\hline
\end{tabular}

NICU neonatal intensive care unit PICU pediatric intensive care unit, $I C U$ intensive care unit, SC surgical center

\subsection{Identification and the main isolated organisms}

Overall, the fungi were identified by conventional methods that focused on both the colony macromorphological characteristics and the conidia micromorphology of the etiological agents. Only Maldonado-Vega et al. (2014) employed molecular techniques (amplification of the ITS1-5.8S-ITS2 region) to identify the fungal filamentous strains after they obtained colonies in a traditional medium. 
Regarding yeast identification, Krajewska-Kułak et al. (2007) used the commercial system Candida ID API 20C AUX (bioMerieux, France), while Calumby et al. (2019) applied CHROMagar Candida ${ }^{\circledR}$.

Among the selected studies, few identified the fungi at the species level which limited the results comparison between species in different studies.

The main filamentous fungal genera found in different environmental studies were (in decreasing order): Aspergillus spp. (24 studies), Penicillium spp. (23 studies), Cladosporium spp. (17 studies), and Fusarium spp. (ten studies). Candida yeast prevailed among unicellular fungi and was cited in ten studies.

Aspergillus spp. constituted $70.5 \%$ of the recovered filamentous fungi in a study conducted in Greece (Krajewska-Kułak et al., 2007) whist in a Brazilian study (Mobin \& Salmito, 2006), A. niger was identified in $60 \%$ of the isolates obtained from the indoor air in the ICUs of public and private hospitals in Teresina, PI. Qudiesat et al. (2009) reported that Aspergillus was the main fungus recovered from neonatal wards in public and private hospitals in Zarqa, Jordan, whereas Gniadek et al. (2010), reported that A. fumigatus was the most frequently isolated Aspergillus species from the indoor air, walls, and equipment in a NICU. A Brazilian study reported recovering the same Aspergillus species from the indoor air from four of ten investigated ICUs (Mobin \& Salmito, 2006).

Penicillium prevailed among the isolates identified by Brazilian authors such as Melo et al. (2009), who analyzed PICU and NICU indoor air in Pouso Alegre, MG; Calumby et al. (2019), who isolated and identified the anemophilous fungal microbiota present in the ICU of a hospital in Maceió, AL; and Gonçalves et al. (2018), who studied the indoor air from a university hospital in Pelotas, RS.

Calumby et al. (2019) reported that Cladosporium constituted $28.1 \%$ of total recovered fungi. Among all the studies that identified Cladosporium, the study of Aboul-Nasr et al. (2014), carried out in Egypt, stood out because these authors isolated C. cladosporioides in all the samples $(100 \%)$ collected in four ICUs and operating rooms. In a study conducted in Brazil, Souza et al. (2019) reported this same species in $80 \%$ of cases, followed by C. herbarum, isolated in $30 \%$ of the cases. Okten and Asan, (2012) recovered Cladosporium in $33.58 \%$ of the samples, with $25 \% C$. cladosporioides prevalence.
Aboul-Nasr et al. (2014) reported that Fusarium was present in $38-63 \%$ of the dust samples from the filters of air-conditioning devices of the four ICUs they studied; in the operating rooms, these authors found Fusarium at 63-100\%; F. oxysporum prevailed in both researched environmental samples. Maldonado-Vega et al. (2014) found Fusarium at 56\% and $21 \%$ in the indoor air of hospitals 1 and 2, respectively. The latter authors recovered $F$. flocciferum in $40 \%$ of the samples, while they equitably isolated $F$. chlamydosporum and F. equiseti (20\% each).

In a study conducted in Saudi Arabia, El-Sharkawy and Noweir (2014) found yeasts in a range spanning from 0.6 to 1.0 Colony-Forming Units (CFU) per cubic meter $\left(\mathrm{m}^{3}\right)$ in the indoor air from operating rooms, ICU, nursery, and pediatric unit. C. albicans was the main species isolated from the NICU indoor air in Greece although non-albicans Candida species were also recovered in small number (KrajewskaKułak et al., 2007) whereas Awosika et al. (2012) also isolated C. albicans from the NICU indoor air and the children's ward. Pantoja et al. (2012) detected Candida spp. in the indoor air of all the ICUs of the three analyzed hospitals. Calumby et al. (2019) identified $C$. krusei and $C$. tropicalis in yeast isolates in equal percentage $(1.7 \%)$. Souza et al. (2019) found $C$. parapsilosis and C. guilliermondii.

With regard to other genera of yeast, Lobato et al. (2009) mentioned isolating Rhodotorula spp. in about $32.69 \%$ of the ICU indoor air samples (adult and neonatal) studied, and Maldonado-Vega et al. (2014) found Cryptococcus albidus.

\subsection{Environmental factors conditioning air contamination}

In hospitals, outbreaks of fungal contamination have become a complication due to construction, demolition, or refurbishment work in/or around the hospitals (Krajewska-Kułak et al., 2007). Some studies have reported that renovation and implantation of a unit inside the hospital coincided with increased colony count of Cladophialophora spp., Aspergillus spp., and Fusarium spp. during the study (Martins-Diniz et al., 2005). However, Qudiesat et al. (2009) associated the building age to the propensity for contamination with fungal propagules: these authors detected a higher level of contamination in hospitals located in older buildings than in new ones. 
Some studies have addressed how seasonality influences the number of fungal spores in suspension or the prevailing fungal genera/species (Martins-Diniz et al., 2005; Quadros et al., 2009; Gniadek et al., 2010; Sales et al., 2011; Macedo et al., 2013; Park et al., 2013). In this context, Sales et al. (2011) pointed out that winter was the season when they isolated the largest number of fungi, whereas Boff et al. (2013) reported a significantly higher fungal concentration in autumn as compared to summer and spring $(P<0.001$ and $P=0.004$, respectively). Gniadek et al. (2010) reported that the number of fungi in the morning samples exceeded the number of fungi in the night samples with average counts that varied from 50 to $2370 \mathrm{CFU} / \mathrm{m}^{3}$. These findings resembled the finding of Macedo et al. (2013), who also verified that fungi prevailed in the morning. They attributed this finding to daily cleaning, which occurred in that period and caused a greater number of particles suspended in the air.

In contrast, Martins-Diniz et al. (2005) described that the afternoon was the period that was prone to the hugest amounts of fungal spores in the air, on account of the higher number of individuals circulating in these hours, which coincided with the visiting period (15 h$17 \mathrm{~h}$ ). Quadros et al. (2009) described similar results, which indicated that the fungal concentration in the indoor air of ICUs was higher in the afternoon (86-62 $\mathrm{CFU} / \mathrm{m}^{3}$ compared to the morning - 191-351 CFU/ $\mathrm{m}^{3}$ ).

Park et al. (2013), who analyzed the indoor air of six hospitals in Korea, showed a higher concentration of fungal spores in the air from $4 \mathrm{pm}$ with a peak at $5 \mathrm{pm}$. However, on average, there was no statistically significant difference between summer and autumn.

Other factors such as air temperature, humidity, and the number of circulating people also influence the level of fungi (Park et al., 2013). Nevertheless, Qudiesat et al. (2009), Macedo et al. (2013), ElSharkawy and Noweir (2014), and Souza et al. (2019) pointed out that, among all the factors, human presence significantly contributed to the fungal diversity observed in the indoor air of hospitals. In the particular case of the NICU, the presence of the mothers and clinical staff contributes to this increase (Macedo et al., 2013).

A study carried out in Porto Alegre, RS, Brazil, reported that the relative humidity of the indoor air in the ICUs varied between 31 and $64 \%$ (median of 51\%) and observed that humidity and fungal concentrations were significantly correlated $(r=0.332 ; P<0.001)$ in closed environments (Boff et al., 2013). Buildings with high internal humidity (76-80\%) allow fungi, especially the genera Penicillium and Aspergillus, to grow, with concomitant release of both conidia and fragments into the atmosphere (Piecková, 2012).

According to Cabral (2010) Aspergillus species grow best in environments with high humidity and temperatures between 25 and $30{ }^{\circ} \mathrm{C}$, However, $\mathrm{Ab}$ basi and Samaei (2019) reported that, at $37{ }^{\circ} \mathrm{C}, \mathrm{A}$. niger was obtained in a density of $26,515 \mathrm{CFU} / \mathrm{m}^{3}$ in a surgical ward for children and Boff et al. (2013), related that temperature and conidium amount in indoor air were positively correlated $(r=0.22$, $P=0.003)$.

\subsection{Maximum air fungal counting}

According to the standards of the Brazilian Ministry of Health and the National Health Surveillance Agency (ANVISA), the Maximum Recommended ValueVMR - for fungal contamination is $750 \mathrm{CFU} / \mathrm{m}^{3}$ in air, and its quality should be frequently checked (usually every 6 months). The air sample must be collected with the aid of an impaction air sampler with a linear accelerator at a flow rate of $28.3 \mathrm{~L} / \mathrm{min}$, positioned at $1.5 \mathrm{~m}$ from the floor (Brazil, 2003). Lower values have been found in Portugal, where the limit is $500 \mathrm{CFU} / \mathrm{m}^{3}$, and in Canada, where $150 \mathrm{CFU} /$ $\mathrm{m}^{3}$ has been established as the limit value (Rao et al., 1996).

The study conducted by Krajewska-Kułak et al. (2007), performed in Greece, presented the highest CFU value, with an average of $1430 \pm 1528 \mathrm{CFU} \mathrm{m}^{3}$ of analyzed air. The same study reported that, comparatively, the average number of fungal colonies isolated from the air in the Neonatal Department was significantly $(P<0.001)$ greater than the number of fungal colonies found in the ICU. This was followed by a study carried out by Maldonado-Vega et al. (2014), who reported 56-408 $\mathrm{CFU} / \mathrm{m}^{3}$ and $32-442 \mathrm{CFU} / \mathrm{m}^{3}$ in indoor air collected in hospitals 1 and 2, respectively, in Léon, Mexico. A Brazilian study accomplished by Quadros et al. (2009) in Florianópolis, SC, reported the maximum value of $351 \mathrm{CFU} / \mathrm{m}^{3}$ in the air collected from the NICU. Pantoja et al. (2012) reported the lowest counts, from 43.75 to $73.67 \mathrm{CFU} / \mathrm{m}^{3}$, in the indoor air collected 
from the ICU of three hospitals in Fortaleza, CE, Brazil.

In addition, in Brazil the $I / E$ ratio must be equal to 1.5 , where $I$ is the amount of fungi in the indoor air, and $E$ is the amount of fungi in the outdoor air. When the $I / E$ ratio is $>1.5$, it is necessary to diagnose the polluting sources diagnosis for corrective intervention although the presence of pathogenic and toxinogenic fungi is unacceptable (Brazil, 2003). However, in countries like Korea, the accepted ratio is lower: equal to 1.0 (Kim et al., 2010).

Regarding to this issue, Sales et al. (2011) obtained 449 fungal isolates in winter, with 93 and 356 samples having been obtained from the indoor and outdoor hospital air $(I / E=0.2)$, respectively. In winter, 258 fungal isolates were obtained, 116 and 142 having been collected from the indoor and outdoor environments $(I / E=0.8)$, respectively. Thus, the number of fungi in the external environment was always higher than the number of fungi in the internal environment. Nevertheless, pathogenic fungi (growing at $37^{\circ} \mathrm{C}$ ) such as A. clavatus, A. fumigatus, and Penicillium spp. were recovered in winter, while Aspergillus sp. and Fusarium sp. grew in the summer.

\section{Discussion}

The number of studies addressing anemophilous fungal infections in PICUs and NICUs is small, but they are important because they aid identification of possible sources of fungal agents in nosocomial infections (Melo et al., 2009; Macedo et al., 2013; Abbasi \& Samaei, 2019). Anemophilous fungi include eukaryotic, single-celled or multicellular organisms. The fungal mycelium is the set of filaments or hyphae that make up the fungi vegetative body (Alexopoulos et al., 1996; Samson, 2011). Spores are easily dispersed and found in the air, where they form the anemophilous microbiota (Alexopoulos et al., 1996). They constitute a potentially pathogenic microbiota that can cause irreversible symptoms in patients with immunosuppressed profile and on prolonged use of antimicrobials (Samson, 2011).

Different exposure locations, collection techniques, identification by conventional or molecular methods, temperature, air humidity, seasons, and human activity explain the variation in the quantity and identity of fungal isolates among the selected studies (Melo et al., 2009; Tang et al., 2015; Abbasi \& Samaei, 2019).

In NICUs/PICUs, air microbiological monitoring is essential, and the air sampling method has a strong influence on the detection of air quality. While collections made with systems like RCS High Flow and SAS Super 180 show 80-90\% efficiency, other systems like RCS Air Sampler, Andersen N6 single stage, and SAS 90 show a relative efficiency for the fungal spores capture from the air (Dharan \& Pittet, 2002; Lee et al., 2004; Yao \& Mainelis, 2007; Li 2011). Nonetheless, more recently, the availability of molecular methods has contributed to accurate pathogens identification (Rocchi et al., 2014; Tang et al., 2015).

The predominant fungi isolated in the studies selected were pathogenic, toxinogenic, or allergic to humans and can cause devastating infections in the high-risk patients (Krajewska-Kułak et al., 2007; Qudiesat et al., 2009; Kim et al., 2010; Gniadek et al., 2017; Souza et al., 2019).

Species of the genus Aspergillus are common in hospitals and play a relevant part as agents of opportunistic nosocomial infections; these species potentially affect any organ, but the lungs are more frequently affected because Aspergillus spores are easily inhaled (Chuaybamroong et al., 2008; Ortiz et al., 2009; Quadros et al., 2009) and have been associated with outbreaks (Lutz et al., 2003; Cristina et al., 2009; Ortiz et al., 2009). However, outbreaks can be performed retrospectively, and are generally defined by epidemiological methods (Tang et al., 2015). Rare events have been properly documented by sampling or laboratory tests associating the presence of conidia in the air and illness of patients (Lutz et al., 2003; Cristina et al., 2009). However, a multidisciplinary team of public health specialists, epidemiologists, microbiologists and engineers could contribute to the understanding of how any event of transmission of pathogens may have occurred and how to intervene to prevent its recurrence (Tang et al., 2015).

There are various factors which play a role in the transmission of airborne diseases such as particle size (droplet $\geq 5 \mu \mathrm{m}$; airborne pathogen $\leq 5 \mu \mathrm{m}$ ) (Saran et al., 2020). Depending on the humidity, the aerodynamic diameter of the conidia of A. fumigatus is about $3.1 \mu \mathrm{m}$ (Tang et al., 2015; Abbasi \& Samaei, 2019). Medical facilities air systems are made up of various components that include the filters/exhaust ventilation 
(remove dust particles and biological contaminants as bacteria, viruses and fungi), and air distribution (speed, flow pattern, direction of movement). Air filters are classified based on their Minimum Efficiency Reporting Value (MERV) rating, which ranges from 1 to 20, with higher values suggesting better filter efficiency (Saran et al., 2020). For example, MERV 10 will be able to filter particles $1-3 \mu \mathrm{m}$ in size, while MERV $>13$, particles from 0.3 to $1 \mu \mathrm{m}$. Filters with MERV $\geq 17$ are called high -efficiency air particle filters (HEPA) (McDowall, 2006).

Highly efficient filters like HEPA can reduce airborne microorganisms by $90-95 \%$, allowing Aspergillus counts in air less than $0.1 \mathrm{CFU} / \mathrm{m}^{3}$ (Abbasi \& Samaei, 2019). Thus, this filter system helps to decrease the risk of Aspergillus outbreaks, since during outbreaks, has been detected 100 or more conidia $/ \mathrm{m}^{3}\left(\mathrm{CFU} / \mathrm{m}^{3}\right)$ suspended in the indoor air (Saran et al., 2020). Among the studies listed in this review, only two mentioned that the NICU/PICU analyzed was equipped with this filter type (Chuaybamroong et al., 2008; Abbasi \& Samaei, 2019). The use of HEPA filtration has been recommended by the Dubai Health Authority in general ICUs (Saran et al., 2020). There is no standardization for the use of HEPA filters in the Brazilian ICU. There is an obligation to maintain hygiene in air-conditioning systems of health care establishments (Brazil, 2018). An improperly maintained air system can be a continuing source of contamination allowing bacteria and fungi spread and survive in the environment (Gniadek et al., 2010; Kim et al., 2010; Maldonado-Vega et al., 2014; Souza et al., 2019).

Other parameters such as temperature, airflow patterns, relative humidity, pressurization in relation to the environment and air changes per hour $(\mathrm{ACH})$ must be considered as environmental risk factor to $\mathrm{HAI}$, especially for neonates. Among these, the $\mathrm{ACH}$ which is defined a measure of the air volume added to or removed from a space in one hour has been highlighted (Saran et al., 2020). The ASHRAE 170 (2008) and the CDC (2005) guidelines recommend a minimum of $12 \mathrm{ACH}$ for isolation hospital rooms. However, a previous study shows that airflow rates of $12 \mathrm{ACH}$ do not necessarily reduce the risk of infection (Memarzadeh \& Xu, 2012). In an enclosed and mechanically ventilated room, the dominant factor that affects the transmission and control of contaminants is the path between the contaminant source and exhaust, since the contaminants are better controlled when this path is uninterrupted by an air stream (Saran et al., 2020), and a secondary factor includes the distance from the contaminant source (Memarzadeh \& $\mathrm{Xu}, 2012$ ).

Aspergillus fumigatus has been highlighted as the main Aspergillus species responsible for more than $80 \%$ of invasive opportunistic fungal infections of the respiratory tract, particularly in ICU patients (Melo et al., 2009; Quadros et al., 2009). This fungal species has been associated with high toxicity due to production of various toxins (approximately 400 compounds), the best known being aflatoxin B1, ochratoxin A, and gliotoxin. Other Aspergillus genus members such as A. flavus, A. niger, and A. ochraceus also produce toxins (Gniadek et al., 2010, 2017).

Fungi belonging to the genus Penicillium are widespread in most terrestrial environments (Melo et al., 2009; Gniadek et al., 2010). In recent years, fungal infections caused by this organism-penicillioses-have become more frequent (Melo et al., 2009; Aboul-Nasr et al., 2014). A wide spectrum of clinical entities has been described, with allergic diseases and superficial mycoses being the most common as reported by Abbassi and Samaei (2019). Another peculiar fact to the genus is the production of mycotoxins including citrine, which can be produced mainly by $P$. citrinum and $P$. chrysogenum (Gniadek et al., 2017).

Cladosporium spp. have also often been isolated. They are agents of brain and skin lesions, brain abscesses with or without meningitis, and chromomycosis (Melo et al., 2009; Calumby et al., 2019). $C$. bantianum has been associated with serious human diseases like brain abscesses, while $C$. herbarum has been related to chromoblastomycosis (Martins-Diniz et al., 2005; Melo et al., 2009). The other Cladosporium species can trigger allergic reactions in sensitive individuals (Okten \& Asan, 2012).

According to Aboul-Nasr et al. (2014) and Abbasi and Samaei (2019), fungi belonging to the genus Fusarium are common in soil, are plant pathogens, and present worldwide distribution. In humans, they have been recognized as opportunistic infection agents, and the most frequent infections are keratitis, skin infections, and onychomycosis. However, such organisms produce several mycotoxins and also have broad resistance to fungicidal drugs (Abbasi \& Samaei, 2019). 
Some studies have suggested that exposure to fungal cell wall $\beta$-glycans and to exo- and endometabolites like mycotoxins, volatile organic compounds, and fungal hemolysins may disturb the activity of natural killer cells (NKs), immunity, and inflammatory reactions (Piecková, 2012; Gniadek et al., 2017). Neonates, mainly premature babies, are considered immunocompromised patients due to immaturity of their $\mathrm{T}$ cells and to incompetence for phagocytosis (PrabhuDas et al., 2011), would then be considered as patients highly susceptible to fungal metabolites. In addition, the skin of neonates is immature and more permeable possibly as a result of inadequate free fatty acid production and alkaline $\mathrm{pH}$. The breakdown of skin integrity in hospitalized neonates can facilitate pathogen entry. Furthermore, IgA production is insufficient in the first days of life, which allows pathogenic microorganisms to invade the mucous membranes of the respiratory and gastrointestinal tracts (Clapp, 2006).

Simultaneously with immune system impairment, the use of broad-spectrum antibiotic therapy has contributed to making neonates more susceptible to nosocomial infections, especially those of yeast origin (Goldstein et al., 2016). The SENTRY global antifungal surveillance program reported that Candida albicans, which causes invasive candidiasis, remains the most prevalent species. However, in South American countries, $C$. parapsilosis is the second most common Candida species underlying invasive infections (Pfaller et al., 2019). The rise in the number of infections with $C$. parapsilosis can be a marker for precarious hospital care practices because this organism colonizes the skin and can be transmitted through cross-infection in the health area (Friedman \& Schwartz, 2019). This denotes concern about the emergence of invasive infections due to fluconazoleresistant $C$. parapsilosis isolates (Berkow \& Lockhart, 2017). In NICUs in Brazil, C. parapsilosis has recently been isolated from neonates, mothers, and the environment (de Paula Menezes et al., 2020).

One of the most worrying alterations in the epidemiology of invasive candidiasis worldwide has been the emergence of the species $C$. auris, a multiresistant organism with efficient nosocomial transmission (Friedman \& Schwartz, 2019). This species was described in Japan in 2009 (Satoh et al., 2009) and has been reported in countries of five continents (Bidaud et al., 2018). Rudramurthy et al.
(2017) performed a retrospective study to identify risk factors for the acquisition of invasive candidiasis by $C$. auris in patients in the ICU as compared to other Candida species. Factors such as previous use of antifungal agents, admission to a public hospital, and underlying lung disease were mainly identified in the study.

Martins-Diniz et al. (2005) reported that C. albicans prevailed in the samples obtained from hospital staff (hands, nails, interdigital spaces, and nasopharynx). Microorganisms colonize the hands of hospital professionals due to the continuous contact of this staff with biological materials (Gniadek et al., 2010). The so-called cross-infections are a major cause of nosocomial infections because they happen when pathogenic microorganisms in one patient are transmitted to another patient either through human contact or objects used by professionals such as the stethoscope (Martins-Diniz et al., 2005; Melo et al., 2009; Gniadek et al., 2010).

To minimize both microbial load and microorganism cross-transmission, hand hygiene is a simple, fast proven action to prevent HAI. Regarding patient safety, hand hygiene is also considered a strong indicator of care quality (Gniadek et al., 2010). Nevertheless, as Martins-Diniz et al. (2005) mentioned that many health professionals unsatisfactorily sanitize their hands and fail to observe recommendations even though they recognize the importance of this measure for the prevention of cross-infections. The World Health Organization (WHO) revealed that $70 \%$ of health professionals do not perform hand hygiene at the five recommended moments: before touching the patient, before conducting a clean/aseptic procedure, after the risk of exposure to body fluids, after touching the patient, and after touching surfaces close to the patient (WHO, 2011). Gniadek et al. (2010) reported recovering Aspergillus strains, one from the nurse's left hand (the only strain isolate from one hand) and four from equipment, namely the inside wall of the incubator, neonatal scales, table for neonatal care, mattress, and instrument.

HAI can jeopardize the quality of care provided to newborns, consequently harming their health and incurring higher costs for hospital institutions. Therefore, monitoring the rate of professionals' adherence to hand hygiene and their respective actions contributes to reducing the occurrence of cross-infections, thereby maximizing the quality and safety of the care 
provided to neonates admitted to the NICU (MartinsDiniz et al., 2005; Venceslau et al., 2012). In addition, although spread by contact is still the main route of infection, airborne infections, both direct and indirect (via the establishment of airborne pathogens in fomites), are probably underestimated (Tang et al., 2015).

\section{Conclusion}

The results presented in this review demonstrate that the presence of anemophilous fungi is frequent in critical areas of hospital environments, specifically in the NICU/PICU. To prevent and to control the fungal microbiota present in the environment and in the fomites and hospital workers' hands, health professionals should adopt preventive measures such as (i) using personal protective equipment when entering the ICUs, (ii) reinforcing measures to control hospital infection in the ICUs, (ii) raising awareness of the existence of fungal infections, (iv) studying ways to promote greater air ventilation so as to ventilate the environment and to prevent fungal spores from accumulating in these environments, (v) cleaning the air-conditioners every two weeks, and (vi) communicating and alerting the health authorities about any deviations from current rules.

Funding This work was partially funded by Coordenação de Aperfeiçoamento de Pessoal de Nível Superior-Brasil (CAPES)_Finance Code 001.

\section{Declaration}

Conflict of interest The authors declare that they have no conflict of interest.

\section{References}

Abbasi, F., \& Samaei, M. R. (2019). The effect of temperature on airborne filamentous fungi in the indoor and outdoor space of a hospital. Environmental Science and Pollution Research, 26, 16868-16876

Aboul-Nasr, M. B., Abdel-Naser, A. Z., \& Amer, E. M. (2014). Indoor surveillance of airborne fungi contaminating intensive care units and operation rooms in Assiut University hospitals. Egypt Journal of Health Science, 2, 20-27

Alexopoulos, C. J., Mims, C. M., \& Blackwell, M. (1996). Introductory mycology. John Wiley \& Sons.
American Society of Health Care Engineering (ASHRAE/ ASHE) Standard, 170-2008. (2008). Ventilation of Health Care Facilities. Atlanta: American Society of Heating, Refrigerating and Air-conditioning Engineers.

Awosika, N. A., Olajubu, F. A., \& Amusa, N. A. (2012). Microbiological assessment of indoor air of a teaching hospital in Nigeria. Asian Pacific Journal of Tropical Biomedicine, 2, 465-468

Berkow, E. L., \& Lockhart, S. R. (2017). Fluconazole resistance in Candida species: A current perspective. Infection and Drug Resistance, 10, 237-245

Bidaud, A. L., Chowdhary, A., \& Dannaoui, E. (2018). C. auris: An emerging drug resistant yeast-a mini-review. Journal of Medical Mycology, 28(3), 568-573

Boff, C., Zoppas, B. C. D. A., Aquino, V. R., Kuplich, N. M., Miron, D., \& Pasqualotto, A. C. (2013). The indoor air as a potential determinant of the frequency of invasive aspergillosis in the intensive care. Mycoses, 56, 527-531

Brazil. (2003). Ministry of Health, Brazilian Health Regulatory Agency (ANVISA). Resolution RE n ${ }^{\circ}$ 9, 16th Jan 2003. Determines the publication of Technical Guidance prepared by the Technical Advisory Group, on Reference Standards for Indoor Air Quality, in artificially heated environments for public and collective use. Brasília, DF, Brazil.

Brazil. (2013). Brazilian Health Regulatory Agency (ANVISA). Diagnostic Criteria for Health Care Related InfectionsNeonatology. Brasilia, 2013. Retrieved April 15, 2020, from http://bvsms.saude.gov.br/bvs/17ard1717nte17a/ 17ard1717nte_diagnosticos_infeccoes_assistencia_saude_ neonatologia.pdf

Brazil. (2018). Low 13.589, Jan 4th, 2018. Provides the maintenance of installation and equipment of air conditioning systems. Brasília, DF. Retrieved December 28, 2020, from http://pesquisa.in.gov.br/imprensa/jsp/visualiza/index. jsp?jornal $=515 \&$ pagina $=1 \&$ data $=05 / 01 / 2018$

Cabral, J. P. (2010). Can we use indoor fungi as bioindicators of indoor air quality? Historical perspectives and open questions. Science of the Total Environment, 408(20), 4285-4295

Calumby, R. J. N., Silva, J. A., Moreira, R. T. F., Araujo, M. A. S., \& Almeida, L. M. (2019). Isolation and identification of anemophilic fungal microbiota in an intensive care unit. Brazilian Journal of Development, 5(10), 19708-19722

Centers for Disease Control and Prevention-CDC. (2005). Guidelines for preventing the transmission of mycobacterium tuberculosis in health-care settings, 2005. Morbidity and Mortality Weekly Report (MMWR), 54(17), 1-141

Check, J., \& Schutt, R. K. (2012). Survey research. In J. Check \& R. K. Schutt (Eds.), Research methods in education. Sage Publications.

Chuaybamroong, P., Choomseer, P., \& Sribenjalux, P. (2008). Comparison between hospital single air unit and central air unit for ventilation performances and airborne microbes. Aerosol and Air Quality Research, 8(1), 28-36

Clapp, D. W. (2006). Developmental regulation of the immune system. Seminars in Perinatology, 30(2), 69-72

Cristina, M. L., Sartini, M., \& Spagnolo, A. M. (2009). Health care-acquired aspergillosis and air conditioning systems. Journal of Preventive Medicine and Hygiene, 50(1), 3-8 
Dal-Bo, K., da Silva, R. M., \& Sakae, T. M. (2012). Nosocomial infections in a neonatal intensive care unit in South Brazil. Revista Brasileira de Terapia Intensiva, 24(4), 381-385

de Paula Menezes, R., de Oliveira, M. S. G., Bessa, M. A. S., Silva, F. F., Alves, P. G. V., Araújo, L. B., et al. (2020). Candidemia by Candida parapsilosis in a neonatal intensive care unit: human and environmental reservoirs, virulence factors, and antifungal susceptibility. Brazilian Journal of Microbiology, 51(3), 851-860

Dharan, S., \& Pittet, D. (2002). Environmental controls in operating theatres. Journal of Hospital Infection, 51(2), 79-84

El-Sharkawy, M. F., \& Noweir, M. E. (2014). Indoor air quality levels in a university hospital in the Eastern Province of Saudi Arabia. Journal of Family \& Community Medicine, 21(1), 39-47

Evans, D. (2002). Systematic reviews of interpretive research: interpretive data synthesis of processed data. Australian Journal of Advanced Nursing, 20(2), 22-26

Friedman, D. Z. P., \& Schwartz, I. S. (2019). Emerging fungal infections: New patients, new patterns, and new pathogens. Journal of Fungi (Basel), 5, E67

Gniadek, A., Krzysciak, P., Twaruzek, M., \& Macura, A. B. (2017). Occurrence of fungi and cytotoxicity of the species: Aspergillus ochraceus, Aspergillus niger and Aspergillus flavus isolated from the air of hospital wards. International Journal of Occupational Medicine and Environmental Health, 30(2), 231-239

Gniadek, A., Macura, A. B., Twaruzek, M., \& Grajewski, J. (2010). Cytotoxicity of Aspergillus strains isolated from the neonatal intensive care unit environment. Advances in Medical Sciences, 55(2), 242-249

Goldstein, N. D., Eppes, S. C., Ingraham, B. C., \& Paul, D. A. (2016). Characteristics of late-onset sepsis in the NICU: Does occupancy impact risk of infection? Journal of Perinatology, 36(9), 753-757

Gonçalves, C. L., Mota, F. V., Ferreira, G. F., Mendes, J. F., Pereira, E. C., Freitas, C. H., et al. (2018). Airborne fungi in an intensive care unit. Brazilian Journal of Biology, 78(2), 265-270

Hornik, C. P., Fort, P., Clark, R. H., Watt, K., Benjamin, D. K., Jr., Smith, P. B., et al. (2012). Early and late onset sepsis in very-low-birth-weight infants from a large group of neonatal intensive care units. Early Human Development, 88(Suppl 2), S69-74

Hoseinzadeh, E., Samarghandie, M. R., Ghiasian, S. A., Alikhani, M. Y., \& Roshanaie, G. (2013). Evaluation of bioaerosols in five educational hospitals wards air in Hamedan, during 2011-2012. Jundishapur Journal of Microbiology, 6(6), e10704

Karlowicz, M. G., Buescher, E. S., \& Surka, A. E. (2000). Fulminant late-onset sepsis in a neonatal intensive care unit, 1988-1997, and the impact of avoiding empiric vancomycin therapy. Pediatrics, 106(6), 1387-1390

Kim, K. Y., Kim, Y. S., \& Kim, D. (2010). Distribution characteristics of airborne bacteria and fungi in the general hospitals of Korea. Industrial Health, 48(2), 236-243

Krajewska-Kułak, E., Lukaszuk, C., Tsokantaridis, Ch., Hatzopoulu, A., Theodosopoyloy, E., Hatzmanasi, D., et al. (2007). Indoor air studies of fungi contamination at the neonatal department and intensive care unit and palliative care in Kavala Hospital in Greece. Advances in Medical Sciences, 52(Suppl 1), 11-14

Lee, K. S., Bartlett, K. H., Brauer, M., Stephens, G. M., Black, W. A., \& Teschke, K. (2004). A field comparison of four samplers for enumerating fungal aerosols I. Sampling characteristics. Indoor Air, 14(5), 360-366

$\mathrm{Li}, \mathrm{K}$. (2011). Molecular comparison of the sampling efficiency of four types of airborne bacterial samplers. Science of the Total Environment, 409(24), 5493-5498

Lobato, R. C., Vargas, V. S., \& Silveira, E. S. (2009). Sazonality and prevalence of airborne fungi in the hospital environment on the South os Rio Grande do Sul, Brazil. Revista da Faculdade de Ciências Médicas, 11(2), 21-28

Lutz, B. D., Jin, J., Rinaldi, M. G., Wickes, B. L., \& Huycke, M. M. (2003). Outbreak of invasive Aspergillus infection in surgical patients, associated with a contaminated air-handling system. Clinical Infectious Diseases, 37(6), 786-793

Macedo, J. I., Kubota, T. H., Matsumoto, L. S., Giordani, A. T., Takayanagui, A. M. M., Mendes, A. A., et al. (2013). Air quality in a hospital environment. Safety and Security Engineering, 134, 737-747

Maldonado-Vega, M., Penã-Cabriales, J. J., De los Santos Villalobos, S. S., Castellanos-Arévalo, A. P., Camarena-Pozos, D., Arévalo-Rivas, B, et al. (2014). Bioaerosoles y evaluación de la calidad del aire en dos centros hospitalarios ubicados en León, Guanajuato, México. Revista Internacional de Contaminación Ambiental, 30(4), 351-363

Martins-Diniz, J. N., Silva, R. A. M., Miranda, E. T., \& MendesGiannini, M. J. S. (2005). Monitoring of airbone fungus and yeast species in a hospital unit. Revista de Saúde Pública, 39(3), 398-405

McDowall, R. (2006). In R. McDowall (Ed.), Fundamentals of HVAC systems. (1st ed.). Elsevier Ltd.

Melo, L. L. S., Lima, A. M. C., Damasceno, C. A. V., \& Vieira, A. L. P. (2009). Environmental fungal flora in pediatric and neonatal intensive care units at a tertiary hospital. Revista Paulista de Pediatria, 27(3), 303-308

Memarzadeh, F., \& Xu, W. (2012). Role of air changes per hour $(\mathrm{ACH})$ in possible transmission of airborne infections. Building Simulation, 5(1), 15-28

Mobin, M., \& Salmito, A. M. (2006). Fungus microbiota in air conditioners in intensive care units in Teresina, Piauí. Revista da Sociedade Brasileira de Medicina Tropical, 39(6), 556-559

Moher, D., Liberati, A., Tetzlaff, J., Altman, D. G. \& PRISMA Group. (2010). Preferred reporting items for systematic reviews and meta-analyses: The PRISMA statement. PLOS Medicine, 6(7), e1000097

Nguyen, M., Leuridan, E., Zhang, T., De Wit, D., Willems, F., Van Damme, P., et al. (2010). Acquisition of adult-like TLR4 and TLR9 responses during the first year of life. PLOS ONE, 5, e10407

Okten, S., \& Asan, A. (2012). Airborne fungi and bacteria in indoor and outdoor environment of the pediatric unit of Edirne government hospital. Environmental Monitoring and Assessment, 184(3), 1739-1751

Ortiz, G., Yagu, G., Segovia, M., \& Catalán, V. (2009). A study of air microbe levels in different areas of a hospital. Current Microbiology, 59(1), 53-58 
Pantoja, L. D. M., Couto, M. S., Junior, N. P. L., de Sousa, B. L., Mourão, C. I., \& Paixão, G. C. (2012). Fungal biodiversity of air in hospitals in the city of Fortaleza, Ceará, Brazil. Revista Brasileira de Promoção da Saúde, 25(2), 192-196

Park, D. U., Yeom, J. K., Lee, W. J., \& Lee, K. M. (2013). Assessment of the levels of airborne, Gram-negative, and fungi in hospital lobbies. International Journal of Environmental Research and Public Health, 10(2), 541-555

Park, J. H., Ryu, S. H., Lee, J. Y., Kim, H. J., Kwak, S. H., Jung, J., et al. (2019). Airborne fungal spores and invasive aspergillosis in hematologic units in a tertiary hospital during construction: a prospective cohort study. Antimicrobial Resistance \& Infection, 8, 88

Pfaller, M. A., Diekema, D. J., Turnidge, J. D., Castanheira, M. \& Jones, R. N. (2019). Twenty years of the SENTRY Antifungal Surveillance Program: Results for Candida species from 1997-2016. In Open forum Infectious diseases. Oxford University Press.

Piecková, E. (2012). Adverse health effects of indoor moulds. Archives of Industrial Hygiene and Toxicology, 63(4), 545-549

Popay, J., Roberts, H., Sowden, A., Petticrew, M., Arai, L., Rodgers, M., et al. (2006). Guidance on the conduct of narrative synthesis in systematic reviews. ESRC Methods Programme, Swindon. Retrieved November 15, 2020, from https://www.lancaster.ac.uk/media/lancaster-university/ content-assets/documents/fhm/dhr/chir/ NSsynthesisguidanceVersion1-April2006.pdf

PrabhuDas, M., Adkins, B., Gans, H., King, C., Levy, O., Ramilo, O., et al. (2011). Challenges in infant immunity: Implications for responses to infection and vaccines. $\mathrm{Na}$ ture Immunology, 12(3), 189-194

Quadros, M. E., Lisboa, H. M., Oliveira, V. L., \& Schimer, W. N. (2009). Indoor air quality in hospitals: A case study and a critical review of current standards. Engenharia Sanitária e Ambiental, 14(3), 431-438

Qudiesat, K., Abu-Elteen, K., Elkarmi, A., Hamad, M., \& Abussaud, M. (2009). Assessment of airborne pathogens in healthcare settings. African Journal of Microbiology Research, 3(2), 066-076

Rao, C. Y., Burge, H. A., \& Chang, J. C. (1996). Review of quantitative standards and guidelines for fungi in indoor air. Journal of the Air \& Waste Management Association, 46(9), 899-908

Rocchi, S., Reboux, G., Larosa, F., Scherer, E., Daguindeau, E., Berceanu, A., et al. (2014). Evaluation of invasive aspergillosis risk of immunocompromised patients alternatively hospitalized in hematology intensive care unit and at home. Indoor Air, 24(6), 652-661

Roen, K., Arai, L., Roberts, H., \& Popay, J. (2006). Extending systematic reviews to include evidence on implementation: methodological work on a review of community-based initiatives to prevent injuries. Social Science \& Medicine, 63(4), 1060-1071

Rudramurthy, S. M., Chakrabarti, A., Paul, R. A., Sood, P., Kaur, H., Capoor, M. R., et al. (2017). Candida auris candidaemia in Indian ICUs: analysis of risk factors. Journal of Antimicrobial Chemotherapy, 72(6), 1794-1801

Sales, E., Sales, E. M. L., Dias, L. F., Costa, F. E. C., \& Loyola, A. B. A. T. (2011). Airborne fungi in an intensive care units and a surgical center of a university hospital. Bioikos, 25(2), 109-115

Samson, R. A. (2011). Ecology and general characteristics of indoor fungi. In O. C. Adan \& R. A. Samson (Eds.), Fundamentals of mold growth in indoor environments and strategies for healthy living. (pp. 101-116). Wageningen Academic Press.

Saran, S., Gurjar, M., Baronia, A., Ghosh, P. S., Raju, G. M., \& Maurya, I. (2020). Heating, ventilation and air conditioning (HVAC) in intensive care unit. Critical Care, 24, 194

Satoh, K., Makimura, K., Hasumi, Y., Nishiyama, Y., Uchida, K. \& Yamaguchi, H. (2009). Candida auris sp. nov., a novel ascomycetous yeast isolated from the external ear canal of an inpatient in a Japanese hospital. Microbiology and Immunology, 53(1), 41-44.

Shah, B. A., \& Padbury, J. F. (2014). Neonatal sepsis: an old problem with new insights. Virulence, 5(1), 170-178

Smith, J., Adams, C. E., King, M. F., Noakes, C. J., Robertson, C., \& Dancer, S. J. (2018). Is there an association between airborne and surface microbes in the critical care environment? Journal of Hospital Infection, 100, 123-129

Souza, A. K. P., Nascimento, J. P. M., Araújo, M. A. S., Pedrosa, K. P. S., Tenorio, B. M., Pires, L. L. S., et al. (2019). Airborne fungi in neonatal intensive care unit of a public hospital in Brazil. International Journal of Current Microbiology and Applied Sciences, 8(12), 1210-1219

Tang, J. W., Wilson, P., Shetty, N., \& Noakes, C. J. (2015). Aerosol-transmitted infections-a new consideration for public health and infection control teams. Current Treatment Options in Infectious Diseases, 7(3), 176-201

Venceslau, E. M., Martins, R. P. P., \& Oliveira, I. D. (2012). Frequency of airborne fungus in critical areas at hospital unit of Aracaju, Sergipe, Brazil. Revista Brasileira Analises Clinicas, 44(1), 26-30

World Health Organization - WHO. (2011). Report on the burden of endemic health care-associated infection worldwide: clean careis safer care. WHO.

Wynn, J. L., \& Levy, O. (2010). Role of innate host defenses in susceptibility to early-onset neonatal sepsis. Clinics in Perinatology, 37(2), 307-337

Yao, M., \& Mainelis, G. (2007). Analysis of portable impactor performance for enumeration of viable bioaerosols. Journal of Occupational and Environmental Hygiene, 4(7), $514-524$

Yoon, H. S. (2010). Neonatal innate immunity and Toll-like receptor. Clinical and Experimental Pediatrics, 53(12), 985-988

Yu, Y., Yin, S., Kuan, Y., Xu, Y., \& Gao, X. (2015). Characteristics of airborne micro-organisms in a neurological intensive care unit: Results from China. Journal of International Medical Research, 43(3), 332-340 